\title{
"This is (Not) a Test": Human Dimensions of Open-Air Biological Weapons Tests, 1949-1969
}

Erin Balcom

In the fall of 1950, eleven San Francisco residents were admitted to Berkeley Hospital with rare bacterial infections. Nearly thirty years later, a Senate subcommittee hearing revealed that the military deliberately released Serratia marcescens, a known opportunistic pathogen, from a naval ship in San Francisco Bay just days before the outbreak, which resulted in the death of Edward J. Nevin. Over the next twenty years, a court case and numerous investigations uncovered an alarming truth about the United States biological weapons program. Government and military personnel have repeatedly and publicly defended the safety and ethics of the research program, insisting that the released substances were "harmless simulants", and that their activities did not qualify as human experimentation. These claims contradict not only official project reports, but the knowledge of civilian scientists and the experiences of the exposed populations, which document the widely ignored human dimensions of the project.

In 1977, the sixty-seven descendents of Edward J. Nevin filed suit against the United States government for the wrongful death of their patriarch in the amount of $\$ 11$ million. ${ }^{1}$ Nevin, a 75 year-old retired pipe fitter, was one of eleven San Francisco residents who developed unexplained bacterial infections in the fall of $1950 .{ }^{2}$ Nearly thirty years later, a Senate subcommittee hearing revealed that the United States Army had intentionally released Serratia marcescens, an opportunistic pathogen, from a naval ship in San Francisco Bay just days before Nevin was hospitalized with bacterial endocarditis. ${ }^{3}$ Nevin's nephew, a prominent lawyer in San Francisco, admitted in 1981 that his family's goal had never been to win the case and collect damages, but to uncover the truth about the government's activities that likely led to his uncle's mysterious death. ${ }^{4}$ Over the course of the trial, previously classified documents were made public, partially through the newly implemented Freedom of Information Act, and also at the request of U.S. attorney John M. Kern, who wanted a "full and complete trial of the issues." Though the court ultimately ruled in favour of the government, Nevin's case exposed alarming truths about the United States biological weapons program: between 1949 and 1969, over two hundred secret experiments were conducted in populated U.S. cities that exposed millions of unsuspecting citizens to bacteria and engineered particles designed to simulate a full-scale biological attack.

\footnotetext{
${ }^{1}$ Leonard A. Cole, Clouds of Secrecy (Maryland: Rowman \& Littlefield Publishing Group, 1988), 76-79.

${ }^{2}$ Wheat, Richard P., Anne Zuckerman, Lowel A. Rantz. "Infection due to Chromobacteria; report of 11 cases". American Medical Association Archive of Internal Medicine 88:4 (1951):461-66.

${ }^{3}$ National Security Subcommittee of the Committee on Government Operations. Cold War era human subject experimentation: hearing before the Legislation and National Security Subcommittee of the Committee on Government Operations, House of Representatives, One Hundred Third Congress, second session, September 28 , 1994. Statement of Dr. Leonard A. Cole, p. 112.

${ }^{4}$ Cole, Clouds of Secrecy, 56.

${ }^{5}$ Ibid., 8 .
} 
The released substances, declared "harmless simulants" in official military reports, ${ }^{6}$ were known toxins and opportunistic pathogens, and have been cited by civilian experts as potential causes for unexplained illnesses among exposed populations. ${ }^{7}$ The government has repeatedly defended the safety, necessity, and ethics of the nation-wide research program, claiming that its aims were strictly defensive and posed no real danger to the public. The stated purpose of the experiments was to study the behaviour of bacterial spores and engineered particles in the atmosphere to assess the vulnerability of American cities to a biological attack, collectively referred to as "Open Air Vulnerability Tests." According to military officials called to publicly defend the experiments, the focus of the research had been the released substances themselves, not the exposed populations, and thus these activities did not qualify as human experimentation and the consent of civilians was not required. ${ }^{8}$ In fact, official statements made by the military during and after the tests appear to dismiss a human dimension to the project altogether. Official reports and the testimonies of government scientists and military personnel scarcely mention the crowds of men, women, and children forced to inhale infectious microbes and toxic particles as they worked, rode the subway, and played in the streets of San Francisco, New York City, and St. Louis.

Open-air vulnerability testing was a program driven by fear and shrouded in secrecy. ${ }^{9}$ Not yet convinced of the potential of biological warfare in a new nuclear age, the U.S. expressed little interest in researching or developing biological weapons until 1942, although its future enemies and allies had launched biological weapons programs shortly after the First World War. ${ }^{10}$ Pressure from Britain and the National Academy of Sciences, combined with uncertainty and fear surrounding the capabilities of the Japanese and Soviet armies drove the U.S. military to develop a bioweapons research program at their principal laboratory in Fort Detrick, Maryland in $1943 .^{11}$ In 1947, in the aftermath of World War II, high-ranking military personnel and researchers from Detrick made several trips to Japan to investigate the bioweapons capabilities of their enemy, initially with the aim of gathering enough information to charge Japanese researchers with war crimes. ${ }^{12}$ The investigation revealed that the Japanese military, under the direction of General Shiro Ishii, had conducted gruesome experiments on Chinese and Japanese civilians that accelerated the development of a vast arsenal of biological weapons. The Japanese program resulted in the murder of an estimated 10,000 civilians, deliberately infected with bubonic plague, anthrax, and numerous other lethal germs. ${ }^{13}$ The "legal scruples" that prevented Britain and the U.S. from experimenting on civilians had also caused them to lag behind enemy nations who had shown less restraint. While Nazi scientists were tried and executed in Nuremberg, Ishii and his

\footnotetext{
6 "Behavior of Aerosol Clouds within Cities," Joint Quarterly Report No. 3, Chemical Corps, U.S. Army, JanuaryMarch 1953, p. 6-122.

${ }^{7}$ Leonard A. Cole, "Bacterium: Testing Germs on the A-Train", Washington Monthly, July 1985. 38-45.

8 Robert Harris and Jeremy Paxman, A Higher Form of Killing: The Secret History of Biological and Chemical Warfare (New York: Random House, 2002). p. 144.

${ }^{9}$ Moreno, Jonathan. Undue Risk: Secret State Experiments on Humans (New York: Routledge, 1999). p. 231

${ }^{10}$ Friedrich Frischknecht. "The history of biological warfare". European Molecular Biology Organization Reports 4 (2003): Special Issue p. S47.

${ }^{11}$ The American Experience: The Living Weapon. Aired on PBS February 5, 2007. Directed by John Rubin. United States.

${ }^{12}$ Regis, Ed. Biology of Doom: America's Secret Germ Warfare Project (Holt Publishing, 2000). p. $108-113$.

${ }^{13}$ Furmanski, Martin, quoted in The Living Weapon, 2007.
} 
team escaped war crimes charges when the United States offered immunity from prosecution in exchange for human data. ${ }^{14}$ American specialists concluded in their 1947 investigations report:

Information with respect to human susceptibility to the diseases could not be obtained in our own laboratories because of the scruples attached to human experimentation...It is hoped that the individuals who voluntarily contributed this information will be spared embarrassment because of it, and that every effort will be made to prevent this information from falling into other hands. ${ }^{15}$

The deal remained a national secret for thirty years. ${ }^{16}$ The investigation in Japan, combined with unconfirmed intelligence surrounding Soviet bioweapons, elevated anxieties among military and government officials. In 1948, former Detrick scientific director Ira Baldwin wrote that the United States was "particularly vulnerable" to a bioweapons attack, and recommended the covert testing of "ventilating systems, subway systems, and water supply systems with innocuous organisms to determine quantitatively the extent to which subversive dissemination of pathogenic biological agents is possible". ${ }^{17}$ In two decades of experimentation, followed by another twenty years of investigations and Congressional hearings, the Army refused to acknowledge the need for ethical and public-health considerations when designing or conducting the experiments, which had turned millions of American citizens into unwitting guinea pigs. Though it was masterfully omitted from testimonies and public statements of military personnel, official project reports, scientific literature from the time, and health records clearly document the human dimensions of the open air vulnerability tests. First, in the elaborate measures taken to deceive the public, local government officials, and members of Congress prior to, during, and in the aftermath of the experiments. Second, in the selection and instrumentalization of human subjects, and finally in the human consequences that befell the exposed populations. The repeated claims by military and government officials that the program was safe, defensive, and not considered human experimentation contradict not only their own reports, but the knowledge of civilian scientists and the experiences of the citizens whose government gambled their health in the name of national security.

\section{Operation Smokescreen}

A concerted effort to deceive the public is the first human dimension to the open-air testing program. According to historian and bioethicist Jonathan Moreno, the decision to conduct field tests over cities was rooted in the ease with which the program could be insulated by secrecy. ${ }^{18}$ Clinical tests, which involved "independently-minded doctors" and scientists eager to publish their results, were difficult to keep secret. ${ }^{19}$ Vulnerability tests, on the other hand, could be carried out by small teams of engineers and government agents, and did not require the consent of any human subject. Only a handful of military personnel and congressmen were briefed on the details of the project, while inquisitive officials were told that the military was conducting a series of "smokescreen experiments" to protect American cities from radar detection

\footnotetext{
${ }^{14}$ Regis, Biology of Doom, p. 110.

${ }^{15}$ Harris and Paxman. A Higher Form of Killing, p. 155.

${ }^{16}$ Williams, Peter, and David Wallace. Unit 731: Japan's Secret Biological Warfare in World War II (New York:

Free Press, 1989). p. 23.

${ }^{17}$ Regis, Biology of Doom, p.115.

${ }^{18}$ Moreno, Undue Risk, p. 232.

${ }^{19}$ Moreno, Undue Risk, p.235
} 
by the Soviet Union ${ }^{20}$. When zinc cadmium sulfide rained down over Minneapolis in 1953, the military planted a false news story in the Minneapolis Tribune explaining that the army was conducting experiments to protect the city from radar detection. ${ }^{21}$ During 'vulnerability tests' in the New York City subway system and the Pentagon, researchers carried false letters stating that they were conducting air-quality control and industrial tests, which were to be shown to any person who questioned their presence or unusual equipment ${ }^{22}$. During the New York test in 1966, bacterial spores were coated in charcoal to reduce their visibility on the cement subway platforms. $^{23}$

Residents, local governments, and police were very rarely informed of the tests. Open-air testing of biological agents is hardly the first time the United States Army has kept its activities secret from the public - but the decision to also keep Congress and local authorities in the dark was an unusual hallmark of the biological weapons program that has contributed to the suspicion and controversy which surrounds it. The clandestine nature of the open-air tests provokes questions regarding not only the details of government activities, but the motivations behind them. If the ultimate goal of the field tests was to protect American citizens, should this goal not have aligned with those of the municipal governments and law enforcement? In moving personnel and equipment through highly public areas, one would think that cooperation with such agencies would have been an asset to researchers - so why had it been strategically avoided? Widespread ignorance about the bioweapons program persisted in Congress, ${ }^{24}$ which continued to approve increased budgets for the research and development of biological weapons with few questions asked. $^{25}$

At investigational hearings before Congress in 1977 and 1994, the government defended the secrecy that had protected their experiments from public scrutiny, stressing the need to hide their research from the Soviet Union and other enemy states. ${ }^{26}$ The 1948 statement from Ira Baldwin that supposedly launched the United States' vulnerability testing program is rife with paranoia characteristic of the Cold War era:

It is believed generally that espionage agents of foreign countries which are potential enemies of the United States are present already in this country. There appears to be no great barrier to prevent additional espionage agents from becoming established here and there is no control exercised over the movements of people within the United States...The subversive use of biological agents by a potential enemy presents a grave danger to the United States. ${ }^{27}$

The secrecy of the U.S. bio-warfare program rivaled that of the nuclear arm of weapons development. ${ }^{28}$ During a secret 1942 meeting in Washington, D.C., agents were informed that releasing any details of the discussion would result in a 40 year prison sentence and a $\$ 10,000$

\footnotetext{
${ }^{20}$ Harris and Paxman, A Higher Form of Killing, p. 156

${ }^{21}$ Cole, Clouds of Secrecy, p. 61.

${ }^{22}$ Harris and Paxman, Higher form of Killing, p. 156

${ }^{23}$ Cole, Clouds of Secrecy, p. 66

${ }^{24}$ John Rubin, The Living Weapon.

${ }^{25}$ Cole, Leonard A. "Operation Bacterium", Washington Monthly. p.38-45.

${ }^{26}$ Harris and Paxman, A Higher Form of Killing, p. 157

${ }^{27}$ Regis, Ed. The Biology of Doom, quote from Ira Baldwin, p. 115.

${ }^{28}$ Moreno, Undue Risk, p.235
} 
fine. $^{29}$ The need for confidentiality is also owed to the unique threat posed by biological weapons: unlike their nuclear counterparts, bioweapons are simple, inexpensive, and easily produced on mass. While a nuclear program required vast resources, virtually any country could acquire a considerable stock of deadly biological agents. For the next thirty years, the federal government would abandon ethics and standards of justice to protect their nation from an imminent war with unknown weapons.

\section{Human Subjects}

The military justified their refusal to communicate with the public and the absence of medical personnel by arguing that the open-air tests do not constitute human experimentation, and therefore, the informed consent of citizens was not required. Though the stated purpose of the experiments was to study the movement of biological agents in urban environments, there is substantial evidence that the military not only had an interest in simulant-human interactions, but that they had been strategic in their selection of populations to be exposed during the tests. At the 1977 Senate subcommittee hearing on biological weapons, the military argued that the presence of human beings at the experimental sites had been "purely coincidental," and that exposed citizens were "unwitting bystanders, not targets." ${ }^{30}$ In light of this, several critics, including microbiologist and physician Stephen Weitzman, questioned the necessity of conducting the experiments in cities at all:

It is unclear to me what additional information was gained by releasing bacteria in the New York City subways...that could not be gathered by a similar experiment done in the tunnels of a deserted mine shaft; or why in studying aerosolization patterns unpopulated areas could not be used, instead of populated cities. ${ }^{31}$

Details of the design and execution of the experiments suggest that the presence of civilians in the urban laboratory was more than coincidental. In assessing the vulnerability of American cities to a biological attack, researchers were interested in measuring the rate and distance at which 'simulants' would disseminate as people went about their regular activities. ${ }^{32}$ As commuters in the New York subway collected spores on their clothing, they carried them to their places of work, to shopping centres, and into their homes. Researchers may not have intended to cause illnesses among civilians, but they were interested in how the movements and interactions of the exposed facilitated the spread of potential diseases. The presence and movement of civilians was integral to obtaining useful data - to say that the project did not have human subjects is a transparent attempt by the military to escape accountability. Had the tests been made public prior to their execution, many civilians may have modified their behaviour to avoid being exposed to the Army's "simulants", corrupting the entire study. Citizens were left uninformed not only because their consent was not required, but because an ignorant sample of civilians was a requirement in the project's research model.

Several experiments deliberately exposed specific populations to bacteria and toxic particles. During early tests in Minneapolis, the military was challenged by inquisitive civilians and local

\footnotetext{
${ }^{29}$ The Living Weapon directed by John Rubin.

${ }^{30}$ Moreno, Undue Risk, p. 231

${ }^{31}$ United States Committee on Human Resources. Subcommittee on Health and Scientific Research of the Committee on Human Resources: Biological Tests Involving Human Subjects by the Department of Defense, March 8th, 1977. Statement of Dr. Stephen Weitzman, p. 265

${ }^{32}$ Moreno, Undue Risk, p. 214.
} 
authorities who were eager to uncover the true nature of the experiments. According to reports, the public in Minneapolis had shown "considerable interest" spray zinc cadmium sulfide, a fluorescent particle known to be toxic in certain quantities, over residential and commercial areas. One Park Commissioner had apparently resisted the military's activities, and was subsequently removed from his post. ${ }^{34}$ In response to the difficulties encountered in Minneapolis, the experiment was relocated to the poorest districts of St. Louis, Missouri in the spring of 1953. The decision to concentrate the tests in St. Louis slums and increase police surveillance in the area was based on a theory expressed in the project report that poor residents were less likely to question the presence of strange equipment and men in their neighborhoods, and were easily controlled by local authorities.

As it does in many human experimentation histories, race underpinned the selection of human subjects very early into the program. In 1951, the U.S. Navy shipped a container to a base in Norfolk, Virginia that had been intentionally contaminated with Serratia marcescens, Bacillus globigii and Aspergillus fumigatus. ${ }^{35}$ The latter species had been chosen because it was believed that African American workers at the base were particularly susceptible to A. fumigatus infections, enabling the military to study the efficiency with which the pathogen spread among employees involved in mail and shipments. ${ }^{36}$ The military justified the test by arguing that an enemy attack may target African Americans specifically with a more lethal form of the fungus, and that the vulnerability of shipment and supply workers needed to be studied in order to develop countermeasures which protect those most vulnerable to infection. Portions of the report became public through the Freedom of Information Act in 1980, and revealed a greater concern for the impact of such an attack on the Naval Supply System than for the welfare of African Americans, the unwitting subjects of the experiment:

Within this [Naval Supply System] there are employed large numbers of laborers, including many Negroes, whose incapacities would seriously affect the operation of the supply system. Since Negroes are more susceptible to [certain families of fungus] than are whites, this fungus disease was simulated by using Aspergillus fumigatus Mutant C-2. ${ }^{37}$

When questioned in 1980, Pentagon spokesmen insisted that no illnesses or adverse health effects resulted from the 1951 experiment, yet cited no source to validate this claim, just as there had been no source to verify the initial safety of the simulants. ${ }^{38}$ In the 1977 Senate hearings, the army had already revealed that there were no attempts to monitor the health of exposed citizens during any of the tests. ${ }^{39}$

\section{Human Consequences}

\footnotetext{
33 "Behavior of Aerosol Clouds within Cities," Joint Quarterly Report No. 3, Chemical Corps, U.S. Army, JanuaryMarch 1953, p.118.

${ }^{34}$ Cole, Clouds of Secrecy, p. 68.

${ }^{35}$ Harris and Paxman, A Higher Form of Killing, p. 157

${ }^{36}$ Moreno, Undue Risk, p. 231

${ }^{37}$ Cole, Clouds of Secrecy, "Quoted in News Release from the Office of Congressman G. William Whitehurst, $2^{\text {nd }}$ District Virginia, September 17, 1980", p. 55.

${ }^{38}$ Moreno, Undue Risk, p. 42.

${ }^{39}$ Cole, Clouds of Secrecy, p.54.
} 
When called forward to defend the ethics and safety of the program, researchers and military officials repeat the rhetoric of decades-old project reports - consistently underestimating the risks to public health posed by the tests, and ultimately failing to make considerations regarding human health and dignity. It is a curious thing that the U.S. biological weapons program is considered only secondarily as a medical operation, and has not included the participation of the Surgeon General or even the Army Medical Department since $1944 .{ }^{40}$ In contrast, physicians and medical professionals have historically found prominent roles in the research and development of chemical and nuclear weapons. ${ }^{41}$ Instead, the majority of bioweapons research, particularly the open-air tests of the 1950s and 60s, has been a project of engineers, with the role of physicians and biologists diminished if not completely absent. The lack of medical personnel involved likely accounts for the failure to acknowledge the potential health consequences of the released 'simulants', and as Jonathan Moreno writes in Undue Risk, the absence of ethical contemplation:

...U.S. field tests were the province of engineers. Though there are now university courses on engineering ethics, traditionally engineers have been trained to think in terms of what can be physically accomplished rather than in terms of what is ethical to try to accomplish...the engineer's normal ways of operating and professional socialization did not historically include ethical assessments [as they have for physicians]. ${ }^{42}$

A diverse cocktail of so-called 'simulants' were used by the military throughout the tests, and though military reports fail to indicate it, many posed known threats to humans. When the army sprayed zinc cadmium sulfide over the San Francisco coastline, the slums of St. Louis, and elementary schools in Minneapolis, ${ }^{43}$ the safety of the particle had not yet been established, though some animal studies had suggested it was toxic at certain doses. ${ }^{44}$ Anecdotal evidence from communities where residents were exposed to the fluorescent chemical in the 1950s and 1960s link zinc cadmium sulfide to reproductive disorders and certain cancers. ${ }^{45}$ The military insists that it was not aware of the health effects of zinc cadmium sulfide at the time, ${ }^{46}$ though a study published in 1932, twenty years before spraying commenced, had shown that "inhalation or ingestion of even small amounts of cadmium or its compounds can pose serious dangers to human health." ${ }^{47}$ Under pressure from Congress, the United States National Research Council conducted an "exhaustive, independent review" and "found no evidence that exposure to zinc cadmium sulfide at [the experimental] levels could cause people to become sick." ${ }^{48}$ Leonard A.

\footnotetext{
${ }^{40}$ Moreno, Undue Risk, p. 44

${ }^{41}$ Harris and Paxman, Higher Form of Killing, p. 155.

${ }^{42}$ Moreno, Undue Risk, p. 235

${ }^{43}$ Rogers Worthington, “Army Test Raises Accusations”, Chicago Tribune, July 15, 1994.

${ }^{44}$ Prodan, L. Cadmium poisoning: I. The history of cadmium poisoning and the uses of cadmium. Journal of Industrial Hygiene 14 (1932) 14: 132-155.

${ }^{45}$ Cole, Clouds of Secrecy, p.47.

${ }^{46}$ Moreno, Undue Risk, p. 234.

${ }^{47}$ National Security Subcommittee of the Committee on Government Operations. Cold War era human subject experimentation: hearing before the Legislation and National Security Subcommittee of the Committee on Government Operations, House of Representatives, One Hundred Third Congress, second session, September 28 , 1994.Statement of Senator Paul David Wellstone, p.10.

${ }^{48}$ Warren E. Leary. "Secret Army Chemical Tests Did Not Harm Health, Report Says", The New York Times, May $15,1997$.
} 
Cole, who presented at the 1994 Cold War Hearings on human experimentation, was critical of this claim:

I have looked at the scientific literature...It is true that some would suggest that at very, very low concentration, cadmium may not offer the toxicity suggested by the 1932 report. But it seems to me that when you are going to be spreading that material around millions of people it would be prudent to err on the side of caution. $^{49}$

The same disregard for public safety was shown in the Army's use of bacterial simulants, particularly Serratia marcescens, and the microbe responsible for Edward J. Nevin's death. The bacteria was deemed benign by the military and valued for their easily traceable red colour. ${ }^{50}$ When eleven patients were admitted to Stanford University Hospital with Serratia infections in September 1950, doctors found the occurrence so unusual that they published their findings in a medical journal. ${ }^{51}$ Upon learning of the outbreak in San Francisco, the military assembled a secret panel to evaluate the situation. ${ }^{52}$ Though the infections occurred only three days after the Army had sprayed the city with the bacteria, and Serratia infections had never been reported at Stanford Hospital, the panel concluded that the occurrence was merely "coincidental", that the infections were hospital-borne, and that open-air tests with the simulant were to continue, "even over populated areas when such studies are necessary for the advancement of the biological warfare program." ${ }^{53}$ The rate of pneumonia in Calhoun County, Alabama nearly tripled in the same year the military conducted tests with bacterial simulants, and returned to its normal level of 4.6 percent one year after the test. ${ }^{54}$

At the 1977 hearing before Congress, military officials reiterated that Serratia did not cause illness, and even if it had, such knowledge was not available to medical professionals at the time of the tests in 1950. In fact, studies of infections with Serratia marcascens among the elderly and immuno-compromised were published as early as $1946 .{ }^{55}$ This knowledge, if not confirming the dangers of the organism to military researchers, should have at least garnered pause before it was dispersed by the tonne over American cities. The Army had either failed to sufficiently research the public health dangers of their study, or had willfully ignored such risks in pursuit of their research goals.

Experimental reports, if they mention the presence of humans at all, portray civilians as a homogenous group that existed outside of the interests of the study. This led to a failure among

\footnotetext{
${ }^{49}$ National Security Subcommittee of the Committee on Government Operations. Cold War era human subject experimentation: hearing before the Legislation and National Security Subcommittee of the Committee on Government Operations, House of Representatives, One Hundred Third Congress, second session, September 28, 1994, Statement of Dr. Leonard A. Cole, p. 133.

${ }^{50}$ Moreno, Undue Risk. p 232

${ }^{51}$ Wheat, Richard P., Anne Zuckerman, Lowel A. Rantz. "Infection due to Chromobacteria; report of 11 cases". American Medical Association Archive of Internal Medicine 88:4 (1951):461-66.

${ }^{52}$ National Security Subcommittee of the Committee on Government Operations. Cold War era human subject experimentation hearing. Statement of Dr. Leonard A. Cole, p. 132.

53 Ibid.

${ }^{54}$ United States Committee on Human Resources. Subcommittee on Health and Scientific Research of the Committee on Human Resources: Biological Tests Involving Human Subjects by the Department of Defense, March 8th, 1977. Statement of Senator Richard Schweiker, p. 18.

${ }^{55}$ Paine, TF. Illness in man following inhalation of Serratia marcescens. 1946. Journal of Infectious Diseases, November 1946. 79 (3): 226-32.
} 
Army researchers to recognize the threat their experiment posed to health of the elderly and ill, such as Edward J. Nevin, who were not protected from exposure to the military's simulants. Researchers also did not account for the "wind conditions or ventilation systems in buildings" which may "concentrate organisms, exposing people to high doses of bacteria." ${ }^{56}$

Because the military made no effort to monitor the health of exposed populations, there is no way of knowing the full extent of health consequences the emerged from open-air testing. The carelessness with which the military released potentially harmful substances over populated cities reveals a disregard for the health and safety of civilians, especially when faced with international uncertainty and threats to national security. At the 1977 and 1994 hearings, government and military officials continued to defend the open-air research program, despite mounting evidence that the released simulants were harmful. One Army public affairs officer went so far as to say that the Bacillus sprayed during the tests was not a true biological agent, but one that "mimics characteristics of a biological material" - a statement that a judge ruled "pure doublespeak." ${ }^{57}$ The statement was an attempt by the military to avoid criticism under the 1969 law which required the military to inform civilians if their experiment involved exposure to biological or chemical agents.

\section{In Our Defense}

Arguably the only human dimension discussed by the military with regard to open-air vulnerability testing is its stated purpose of promoting national security and protecting civilians from an enemy-launched bioterror attack. At the 1977 and 1994 hearings, officials portrayed the open-air tests as strictly a 'defensive' endeavor, likely in an attempt to paint the project in a positive light and relieve anxieties among citizens who had recently learned of their exposure to the test substances. However, reports from the time of the tests, the statements of officials throughout investigations, and the knowledge gathered from the overall research program provide evidence that the open-air experiments cannot be understood as purely defensive research.

In 1951, near the launch of the vulnerability-testing program, the military apparently did not feel the need to conceal the non-defensive applications of their research. A report by the Joint Chiefs of Staff stated explicitly that the Army regarded open-air tests as "providing useful information for offensive purposes, an aim also subscribed to by the CIA." ${ }^{58}$ In the report of the 1966 test in New York, several "countermeasures" were suggested to protect civilians from an attack on the subway lines. All of these suggestions, including mass vaccinations and intermittently locking car doors, were impractical and never attempted. ${ }^{59}$ In fact, transit authorities were never informed that the tests occurred, let alone what their next course of action should be. In twenty years of testing, not a single defensive measure was implemented. ${ }^{60}$

What did amount from two decades of open-air tests were efficient methods for distributing biological agents. In the New York City subway system, spores were covertly disbursed by dropping germ-filled light-bulbs onto tracks - an invention of the Special Operations Division

\footnotetext{
${ }^{56}$ United States Committee on Human Resources. Subcommittee on Health and Scientific Research of the Committee on Human Resources: Biological Tests Involving Human Subjects by the Department of Defense, March 8th, 1977. Statement of Dr. Stephen Weitzman,. p. 263.

${ }^{57}$ Bruce Hilton. "Doublespeak Again Comes to the Rescue". San Francisco Examiner, December 10, 1989.

${ }^{58}$ Levy, Barry, S. War and Public Health (Oxford University Press, 2000). p.104

${ }^{59}$ Cole, Clouds of Secrecy, p. 67

${ }^{60}$ Ibid.
} 
Engineering Laboratory. ${ }^{61}$ Data acquired from the Japanese had demonstrated the lethality of weaponized anthrax and plague, but open-air tests in the United States demonstrated how the deadly agents could be released and move through the atmosphere. Secret "mock attacks" ${ }^{62}$ over American cities may not have led to useful defensive measures, but they did provide "critical information about how thick a cloud of bacteria needed to be to spread diseases successfully." ${ }^{63}$

On November 25, 1969, President Richard M. Nixon delivered a speech from Camp Detrick that renounced all offensive research in biological warfare:

The United States shall renounce the use of lethal biological agents and weapons, and all other methods of biological warfare. The United States will confine its biological research to defensive measures such as immunization and safety measures. ${ }^{64}$

Curiously, open-air testing of biological simulants over American cities ceased that very same year.

\section{Conclusion}

The United States military has never apologized for exposing millions of unwitting civilians to potentially harmful bacteria and particles. In 1985, the Pentagon maintained that there would be no "legal or ethical barriers" to resuming open-air vulnerability testing. ${ }^{65}$ It appears that this assessment was correct, as in the summer of 2012, the Department of Homeland Security released Bacillus globigii into the Boston subway line to test sensors capable of detecting a biological attack. ${ }^{66}$ Like Serratia marcescens, Bacillus globigii is capable of causing lethal disease in immunocompromised individuals. ${ }^{67}$ This time, by law, the government informed civilians of the tests beforehand, and assured them that the project posed no threat to their health, and was in fact being conducted in the interests of protecting their safety. ${ }^{68}$

Between 1949 and 1969, over one million American civilians served as non-consenting volunteers for a national security project that exposed them to potentially harmful substances. During the 2012 tests, just as they had over thirty years ago, officials openly defended the safety of the project, and apparently did not find an ethical dilemma in once again transforming public spaces into government laboratories. When the Nevin case and Senate hearings revealed details of the "vulnerability tests" in the early 1970s, federal and military officials were forced to defend their project to a public that feared a bioterrorist attack, but now also had a reason to fear their government. A number of generalized and ultimately false statements regarding the safety, defensive purpose, and ethics of the program enabled the government to appease civilian

\footnotetext{
${ }^{61}$ Regis, Biology of Doom, p. 197

${ }^{62}$ Jim Carlton. "Of Microbes and Mock Attacks: 51 Years Ago, The Military Sprayed Germs on U.S. Cities", Wall Street Journal, October 26, 2001.

${ }^{63}$ Harris and Paxman, A Higher Form of Killing, p. 164

${ }^{64}$ Regis, Biology of Doom, p. 207

${ }^{65}$ Leonard A. Cole, "Operation Bacterium", Washington Monthly.

${ }^{66}$ Department of Homeland Security Science and Technology Directorate. "Environmental Assessment of Bacillus subtilis Particles to Challenge Bio-Detection Sensors in Subway Stations" Version 15, January 2012. p.12.

${ }^{67}$ de Boer, AS, Diderichsen, B. 1991. "On the safety of Bacillus subtilis and B. amyloliquefaciens: a review". Applied Microbiology and Biotechnology, October 1991, 36(1):1-4.

${ }^{68}$ Department of Homeland Security Science and Technology Directorate. "Environmental Assessment of Bacillus subtilis Particles to Challenge Bio-Detection Sensors in Subway Stations", Version 15, January 2012. p. 43.
} 
anxieties while refusing to take responsibility for the health of exposed citizens. In twenty years of research, U.S. residents were left no more protected from a bioweapons attack than they had been in 1942. It is also interesting to note that in this period, which was characterized by nebulous fears of an enemy-launched attack, the only organization to successfully endanger the health of American civilians with bio-weapons technologies was the United States government.

\section{Bibliography}

Carlton, Jim. "Of Microbes and Mock Attacks: 51 Years Ago, The Military Sprayed Germs on U.S. Cities", Wall Street Journal, October 26, 2001.

Cole, Leonard A. "Operation Bacterium: Testing Germs on the A-Train", Washington Monthly, July 1985. p 38-45.

Cole, Leonard A. Clouds of Secrecy (Maryland: Rowman \& Littlefield Publishing Group, 1988).

Committee on Government Operations. Cold War era human subject experimentation: Hearing before the Legislation and National Security Subcommittee of the Committee on Government Operations, House of Representatives, One Hundred Third Congress, second session, September 28, 1994.

de Boer, AS, Diderichsen, B. 1991. On the safety of Bacillus subtilis and B. amyloliquefaciens: a review. Applied Microbiology and Biotechnology, October 1991, 36(1):1-4.

Department of Homeland Security Science and Technology Directorate. "Environmental Assessment of Bacillus subtilis Particles to Challenge Bio-Detection Sensors in Subway Stations. Version 15. January 12th, 2012.

Frischknecht., Friedrich. "The history of biological warfare". European Molecular Biology Organization Reports. 4: Special Issue, 2003, p. S47

Harris, Robert and Jeremy Paxman. A Higher Form of Killing: The Secret History of Biological and Chemical Warfare (Random House, 2002).

Hilton, Bruce. "Doublespeak Again Comes to the Rescue". San Francisco Examiner, December $10,1989$.

Leary, Warren E. "Secret Army Chemical Tests Did Not Harm Health, Report Says", The New York Times, May 15, 1997

Levy, Barry, S. War and Public Health (Oxford University Press, 2000).

Moreno, Jonathan. Undue Risk: Secret State Experiments on Humans (W.H. Freeman Publishing, 1999). 
Paine, TF. Illness in man following inhalation of Serratia marcescens. 1946. Journal of Infectious Diseases, 1946, November. 79 (3): 226-32.

Prodan, L. 1932. Cadmium poisoning: I. The history of cadmium poisoning and the uses of cadmium. Journal of Industrial Hygiene, 14: 132-155.

Regis, Ed. Biology of Doom: America's Secret Germ Warfare Project (Holt Publishing, 2000).

Rubin, John. The American Experience: The Living Weapon. Produced, Written, and Directed by John Rubin. United States: PBS. 2007. Online Access: http://digital.films.com/PortalViewVideo.aspx?xtid=44077 [Courtesy of University of Alberta Libraries]

United States. Congress. Senate. Subcommittee on Health and Scientific Research of the Committee on Human Resources: Biological Tests Involving Human Subjects by the Department of Defense, March 8th, 1977. p. 18-265.

United States Army Chemical Corps. "Behavior of Aerosol Clouds within Cities," Joint Quarterly Report No. 3, Chemical Corps, U.S. Army, January-March 1953, p. 6-122.

Wheat R.P. , Zuckerman A., Rantz L.A. Infection due to chromobacteria; report of 11 cases. American Medical Association Archive of Internal Medicine. 1951 Oct;88(4):461-466.

Williams, Peter, and David Wallace. Unit 731: Japan's Secret Biological Warfare in World War II (Free Press, 1989).

Worthington, Rogers. “Army Test Raises Accusations”, Chicago Tribune, July 15, 1994. 